\title{
Multifocal acquired demyelinating sensory and motor neuropathy
}

Figure $\quad$ MRI and fascicular biopsy of the right brachial plexus

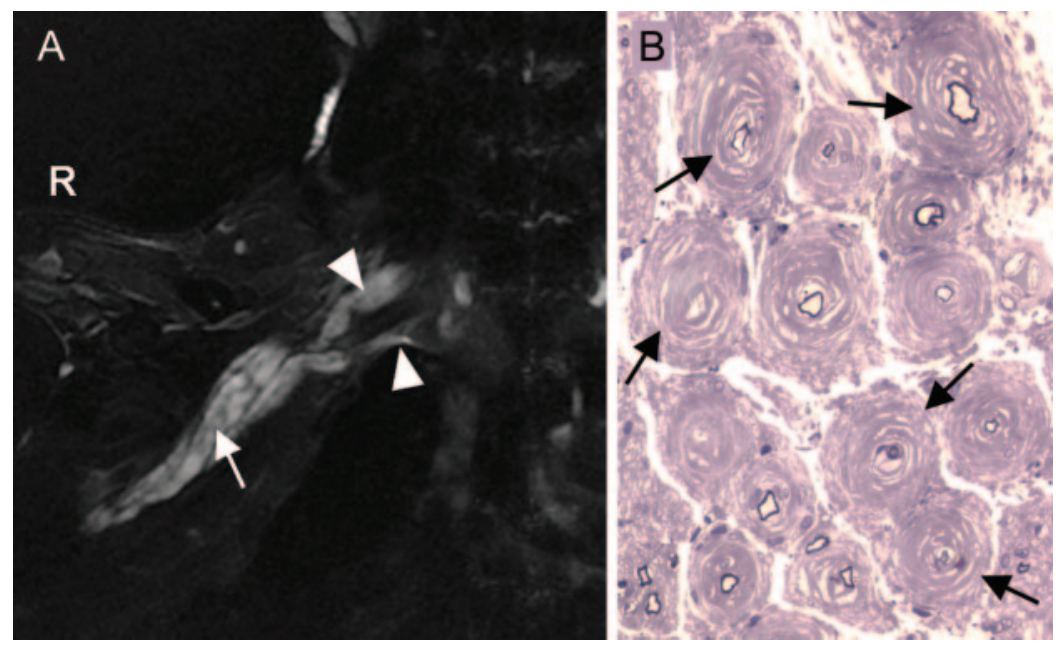

(A) MRI of the right C7 and C8 nerve roots (arrowheads) and brachial plexus (arrow) demonstrated marked swelling and hyperintensity on T2-weighted sequences. (B) Fascicular biopsy of the right brachial plexus revealed numerous large "onion-bulbs" (reflecting chronic demyelination/remyelination), surrounding small, thinly myelinated axons on Toluidine blue staining (arrows).

A 54-year-old man presented with a 10-year history of progressive weakness, tingling, and pain involving the left lower and right upper extremities. Examination revealed moderate weakness of right radial, median, ulnar, and left tibial-innervated muscles with sensory loss in right hand digits $4 / 5$ and the left sole. Electrophysiologic testing disclosed a left sciatic neuropathy (tibial division) and right sensorimotor brachial plexopathy with axon loss physiology. A diagnosis of multifocal acquired demyelinating sensory and motor neuropathy (MADSAM), a multifocal variant of chronic inflammatory demyelinating polyneuropathy, was made following an MRI and fascicular biopsy of the right brachial plexus ${ }^{1}$ (figure). Muscle strength, paresthesias, and pain improved following IV immunoglobulin therapy. ${ }^{2}$

\section{Araya Puwanant, MD, David N. Herrmann, MBBCh, Rochester, NY}

Author contributions: Dr. Puwanant contributed to the work by designing the study, analyzing and interpreting the data, and drafting and revising the manuscript. Dr. Herrmann contributed to the work by designing the study, interpreting the data, and revising the manuscript.

A. Puwanant has received funding support from the NIH and the Muscular Dystrophy Association: Clinical Research Training Grant. D. Herrmann reports no disclosures. Go to Neurology.org for full disclosures.

Correspondence \& reprint requests to Dr. Puwanant:araya_puwanant@urmc.rochester.edu

1. Bradley LJ, Wilhelm T, King RH, Ginsberg L, Orrell RW. Brachial plexus hypertrophy in chronic inflammatory demyelinating polyradiculoneuropathy. Neuromuscul Disord 2006;16:126-131.

2. Thomas PK, Claus D, Jaspert A, et al. Focal upper limb demyelinating neuropathy. Brain 1996;119:765-774. 


\section{Neurology}

\section{Multifocal acquired demyelinating sensory and motor neuropathy \\ Araya Puwanant and David N. Herrmann \\ Neurology 2012;79;1742 \\ DOI 10.1212/WNL.0b013e31826e9b62}

This information is current as of October 15, 2012

\section{Updated Information \& Services}

References

Citations

Subspecialty Collections

Permissions \& Licensing

Reprints including high resolution figures, can be found at: http://n.neurology.org/content/79/16/1742.full

This article cites 2 articles, 0 of which you can access for free at: http://n.neurology.org/content/79/16/1742.full\#ref-list-1

This article has been cited by 1 HighWire-hosted articles: http://n.neurology.org/content/79/16/1742.full\#\#otherarticles

This article, along with others on similar topics, appears in the following collection(s):

All Neuromuscular Disease

http://n.neurology.org/cgi/collection/all_neuromuscular_disease

Chronic inflammatory demyelinating polyneuropathy

http://n.neurology.org/cgi/collection/chronic_inflammatory_demyelinat ing_polyneuropathy

Peripheral neuropathy

http://n.neurology.org/cgi/collection/peripheral_neuropathy

Information about reproducing this article in parts (figures,tables) or in its entirety can be found online at:

http://www.neurology.org/about/about_the_journal\#permissions

Information about ordering reprints can be found online:

http://n.neurology.org/subscribers/advertise

Neurology ${ }^{\circledR}$ is the official journal of the American Academy of Neurology. Published continuously since 1951, it is now a weekly with 48 issues per year. Copyright Copyright (? 2012 by AAN Enterprises, Inc.. All rights reserved. Print ISSN: 0028-3878. Online ISSN: 1526-632X.

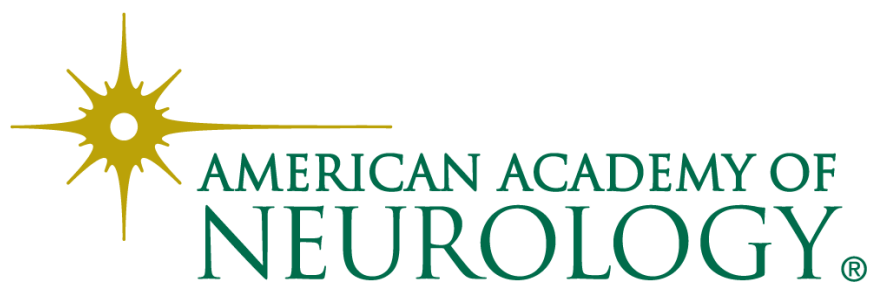

